\title{
The case for decoupling assembly and submission standards to maintain a more flexible registry of biological parts
}

\author{
Razan N Alnahhas ${ }^{\dagger}$, Ben Slater ${ }^{\dagger}$, Yunle Huang, Catherine Mortensen, Jordan W Monk, Yousef Okasheh, \\ Marco D Howard, Neil R Gottel, Michael J Hammerling ${ }^{*}$ and Jeffrey E Barrick
}

\begin{abstract}
The Registry of Standard Biological Parts only accepts genetic parts compatible with the RFC 10 BioBrick format. This combined assembly and submission standard requires that four unique restriction enzyme sites must not occur in the DNA sequence encoding a part. We present evidence that this requirement places a nontrivial burden on iGEM teams developing large and novel parts. We further argue that the emergence of inexpensive DNA synthesis and versatile assembly methods reduces the utility of coupling submission and assembly standards and propose a submission standard that is compatible with current quality control strategies while nearly eliminating sequence constraints on submitted parts.
\end{abstract}

Keywords: Synthetic biology, Biological part, DNA assembly, Gibson assembly, Gene synthesis, BioBrick, Registry of standard biological parts, Assembly standard, Submission standard

The Registry of Standard Biological Parts (hereafter, the Registry) aims to provide a collection of well-characterized genetic parts (BioBricks) with defined behaviors that can be assembled to construct complex biological devices [1]. The genetic parts sent to iGEM teams each year in the DNA distribution kit are derived from the Registry, and iGEM teams are expected to improve the Registry by further characterizing existing parts and by submitting new parts for inclusion. Here we provide evidence that current requirements on DNA sequences for part submission may unnecessarily impede this mission, and propose a new submission standard that would eliminate this problem while minimally impacting current quality control protocols.

As described in BioBricks Foundation RFC 10 and as currently used by the Registry, BioBricks constitute a combined assembly and submission standard. An assembly standard is a procedure for combining multiple biological parts into a device encoded by a single piece of DNA. A submission standard refers only to requirements on the

\footnotetext{
*Correspondence: mhammerling@gmail.com; jbarrick@cm.utexas.edu ${ }^{\dagger}$ Equal contributors

Department of Molecular Biosciences, Institute for Cellular and Molecular Biology, Center for Systems and Synthetic Biology, The University of Texas at Austin, Austin, Texas 78712, USA
}

DNA sequence of a part for it to be archived and redistributed by the Registry. BioBrick parts are typically submitted on the Escherichia coli plasmid pSB1C3, and they must be flanked by defined prefix and suffix sequences containing restriction enzyme sites for 3A assembly [2] (Figure 1A). Critically, these reserved (or "illegal") restriction sites must not be present within the sequence of a BioBrick for it to be compatible with RFC 10 or similar assembly standards. The pSB1C3-derived plasmid can be transformed into E. coli cells to replicate the DNA encoding a part with high fidelity, and the quality and identity of each genetic part in the Registry can be verified by restriction analysis.

At the time BioBricks were introduced, restriction enzyme cloning was the dominant method for assembling multiple DNA sequences into a single construct, and E. coli was the host for nearly all synthetic biology devices. Since the inception of RFC 10, a great variety of new assembly methods have been developed $[5,6]$, including homology-based protocols using enzymes in vitro (Gibson Cloning, Seamless Cloning), in vivo assembly (via yeast recombination), and assembly using type II restriction enzymes (Golden Gate Assembly). Some of these methods can rapidly compose many parts together

\section{Biomed Central}

(c) 2014 Alnahhas et al.; licensee BioMed Central Ltd. This is an Open Access article distributed under the terms of the Creative Commons Attribution License (http://creativecommons.org/licenses/by/4.0), which permits unrestricted use, distribution, and reproduction in any medium, provided the original work is properly credited. The Creative Commons Public Domain Dedication waiver (http://creativecommons.org/publicdomain/zero/1.0/) applies to the data made available in this article, unless otherwise stated. 


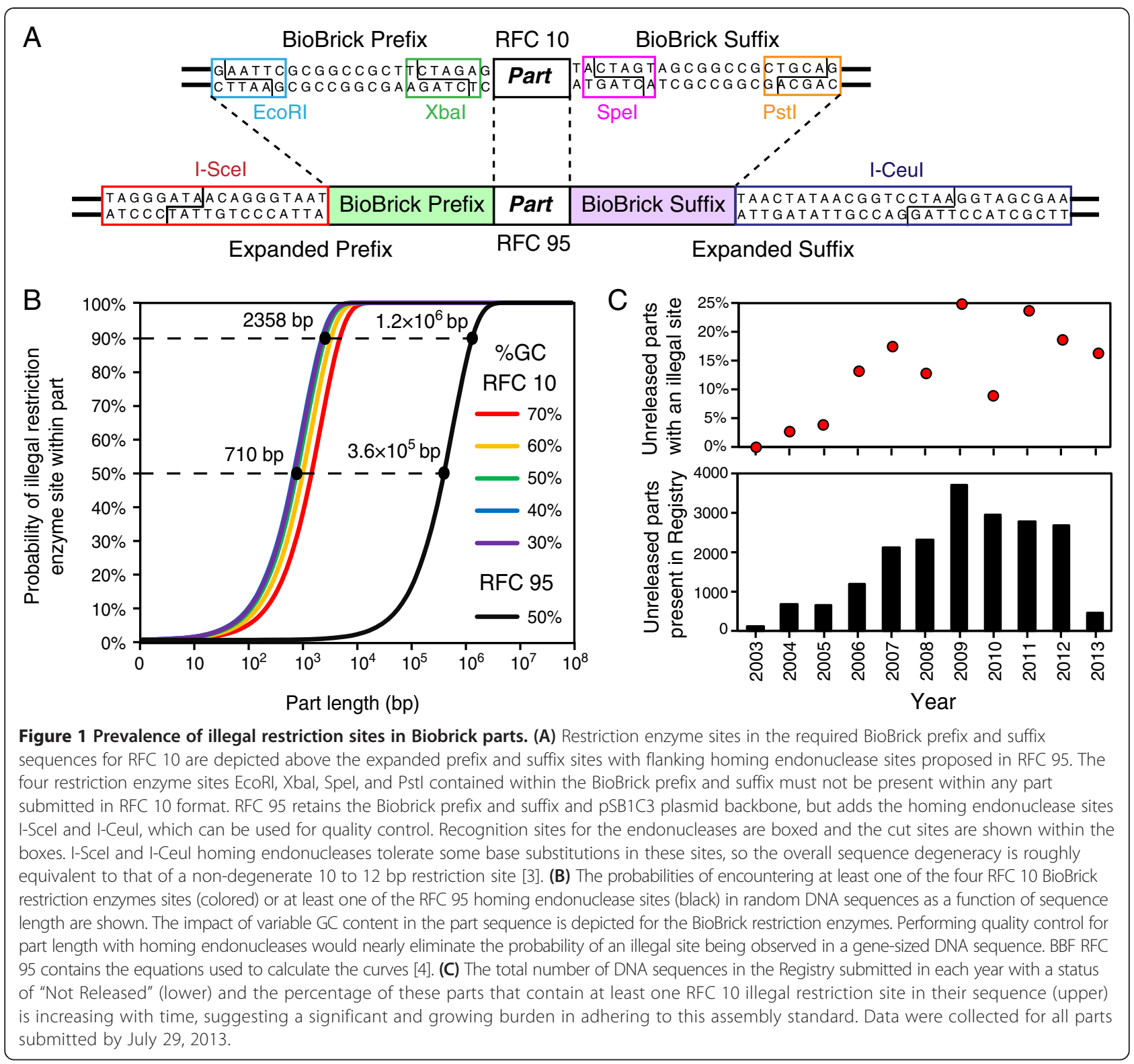

in a single reaction, unlike $3 \mathrm{~A}$ assembly, which requires multiple rounds of restriction cleavage and ligation to concatenate parts. Many of these newer assembly methods also have no inherent requirement that specific base sequences, such as restriction sites, be present or absent in the DNA specifying a component in order for it to be assembled with other parts. When using such methods, there is no need for an assembly standard to be imposed on top of a submission standard. Researchers now employ synthetic biology approaches in many organisms, including plants and animals, where this greater flexibility in the sequences of vectors and genetic parts may be beneficial [7].

As genes and gene clusters with new activities are discovered and iGEM teams seek to add these parts to the Registry, greater incidences of illegal restriction enzyme site sequences are expected to be found within the DNA sequences of prospective parts. While the assembly standard's requirement to remove any illegal restriction sites present in a part may seem a minor inconvenience, calculating the frequency at which restriction sites occur reveals that compliance with the BioBrick RFC 10 (or similar restriction enzyme-based standards) likely burdens most iGEM teams wishing to submit gene-sized or longer parts amplified from genomic sequences to the Registry (Figure 1B). The probability of a random DNA sequence containing at least one of the four BioBrick restriction sites increases rapidly with sequence length, such that a majority of parts derived from natural sequences $>710$ bp will contain a restriction site, and more than $90 \%$ of those $>2360$ bp will [4]. Furthermore, an 


\begin{tabular}{|c|c|c|}
\hline \multirow{2}{*}{$\begin{array}{l}\text { What DNA assembly } \\
\text { methods does your iGEM } \\
\text { team most commonly use? }\end{array}$} & $\begin{array}{l}\text { "One-pot" assembly } \\
\text { methods like Gibson } \\
\text { cloning. }\end{array}$ & $\begin{array}{l}\text { Restriction enzyme } \\
\text { cloning methods like } \\
3 \text { A assembly. }\end{array}$ \\
\hline & $43 \%$ & $57 \%$ \\
\hline \multirow{2}{*}{$\begin{array}{l}\text { Has your team used site-directed } \\
\text { mutagenesis to remove illegal } \\
\text { restriction sites from a part to } \\
\text { submit it to the Registry? }\end{array}$} & Yes & No \\
\hline & $52 \%$ & $48 \%$ \\
\hline \multirow{3}{*}{$\begin{array}{l}\text { Has your team decided not to } \\
\text { submit a part to the Registry } \\
\text { due to the presence of illegal } \\
\text { restriction sites? }\end{array}$} & Yes & No \\
\hline & $36 \%$ & $64 \%$ \\
\hline & \multicolumn{2}{|r|}{$n=44$} \\
\hline
\end{tabular}

Figure 2 Results of a survey sent to iGEM teams regarding illegal restriction sites. Official contacts for all of the 2013 iGEM teams were emailed a link to an anonymous online survey. A total of 44 responses from iGEM team members and their mentors were collected and analyzed.

analysis of parts marked "Not Released" in the Registry -often in this category because they do not adhere to the RFC 10 BioBrick standard and were therefore not accepted for archival and redistribution-shows that the fraction of parts designed by recent iGEM teams that contain an illegal site is $>15 \%$ and appears to be increasing (Figure 1C).

In light of these developments, we argue that it would be beneficial to many iGEM teams and the greater biological engineering community to no longer require compatibility with assembly standards for a DNA part to be deposited in the Registry. To assess user sentiment, we surveyed the 2013 iGEM teams about their preferred assembly methods and experiences with submitting parts to the Registry (Figure 2). Though a majority of teams still primarily used restriction enzyme cloning, 43\% most commonly used "one-pot" assembly methods rather than restriction enzyme cloning, showing that many teams are already adopting these newer methods. We found that $52 \%$ of teams surveyed have used site-directed mutagenesis to remove illegal restriction sites from parts, and 36\% of teams have decided not to submit a part to the Registry due to the presence of illegal restriction sites. Thus, a sizable proportion of our respondents were expending time and effort performing site-directed mutagenesis of already functioning parts to comply with RFC 10—a substantial burden on the productivity of teams.

The Registry needs a submission standard that maintains a simple and rapid method for quality control of submitted parts. As described in RFC 95, this aim could be accomplished by using a less restrictive submissiononly standard where homing endonuclease sites are included outside of the BioBrick prefix and suffix sequences [4]. Homing endonucleases recognize and cleave within long target sequences $(\sim 15-30$ base pairs $)$ in contrast to the short sequences (6-8 base pairs) recognized by most commonly used restriction enzymes. These longer recognition sequences are unlikely to occur in DNA sequences of $<20$ kilobases (Figure 1B), which is approximately the limit of what can be routinely cloned into plasmids in $E$. coli. By placing the homing endonuclease sites outside of the current BioBrick restriction enzyme sites, new parts submitted using this standard would remain backwards compatible with RFC 10 assembly in cases where no BioBrick restriction sites are found in the part.

While DNA synthesis methods are advancing rapidly $[8,9]$, making it more economical for iGEM teams to custom order a limited number of ready-to-use parts, the Registry continues to play an important role in democratizing synthetic biology by distributing a large number of parts at a much lower cost. For a genetic parts repository and registry to remain relevant as technology progresses, it should anticipate these changes and adapt its methods to complement them [10]. This may include adopting greater flexibility by decoupling DNA assembly and submission standards, as described here, as well as more rigorous and standardized expectations for how the operation of genetic parts must be characterized in order for them to be included in the Registry.

\section{Competing interests}

The authors declare that they have no competing interests.

\section{Authors' contributions}

$\mathrm{MJH}$ and JEB conceived the idea of an editorial on this topic. RNA, BS, YH, CM, JWM, YO, MDH, NRG, MJH, and JEB designed the alternative standard. $\mathrm{RNA}, \mathrm{BS}, \mathrm{YH}, \mathrm{MJH}$, and JEB performed probability calculations and analyzed parts in the Registry. RNA, BS, YH, CM, MJH, and JEB made the figures. All authors wrote, edited, and approved the final version of the manuscript.

\section{Acknowledgements}

The 2013 Greensboro-Austin iGEM team acknowledges funding from the U.S. National Science Foundation BEACON Center for the Study of Evolution in Action (DBI-0939454) and from the University of Texas at Austin College of Natural Sciences, Institute for Cellular and Molecular Biology, Center for Systems and Synthetic Biology, and Department of Molecular Biosciences. 
We thank other members of our joint iGEM team, including Robert Newman and students at North Carolina Agricultural and Technical State University; and Mads Kaern and the University of Ottawa iGEM team for useful discussions.

Received: 25 August 2014 Accepted: 11 November 2014

Published: 1 December 2014

\section{References}

1. Canton B, Labno A, Endy D: Refinement and standardization of synthetic biological parts and devices. Nat Biotechnol 2008, 26:787-793.

2. Knight T: Draft standard for BioBrick biological parts. http://hdl.handle.net/ 1721.1/45138.

3. Gimble FS, Wang J: Substrate recognition and induced DNA distortion by the PI-Scel endonuclease, an enzyme generated by protein splicing. J Mol Biol 1996, 263:163-180.

4. Hammerling M, Gottel NR, Alnahas RN, Slater B, Huang Y, Okasheh Y, Howard M, Mortensen C, Monk J, Detelich M, Lannan RS, Pitaktong A, Weaver E, Das S, Barrick JE: BBF RFC 95: Open Sequence Initiative: a part submission standard to complement modern DNA assembly techniques. http://hdl.handle.net/1721.1/81334.

5. Ellis T, Adie T, Baldwin GS: DNA assembly for synthetic biology: from parts to pathways and beyond. Integr Biol (Camb) 2011, 3:109-118.

6. Kahl $\sqcup$, Endy D: A survey of enabling technologies in synthetic biology. J Biol Eng 2013, 7:13.

7. Wang Y-H, Wei KY, Smolke CD: Synthetic biology: advancing the design of diverse genetic systems. Annu Rev Chem Biomol Eng 2013, 4:69-102.

8. Esvelt KM, Wang HH: Genome-scale engineering for systems and synthetic biology. Mol Syst Biol 2013, 9:641.

9. Ma S, Tang N, Tian J: DNA synthesis, assembly and applications in synthetic biology. Curr Opin Chem Biol 2012, 16:260-267.

10. Vilanova C, Porcar M: iGEM 2.0-refoundations for engineering biology. Nat Biotechnol 2014, 32:420-424.

doi:10.1186/1754-1611-8-28

Cite this article as: Alnahhas et al:: The case for decoupling assembly and submission standards to maintain a more flexible registry of biological parts. Journal of Biological Engineering 2014 8:28.

\section{Submit your next manuscript to BioMed Central and take full advantage of:}

- Convenient online submission

- Thorough peer review

- No space constraints or color figure charges

- Immediate publication on acceptance

- Inclusion in PubMed, CAS, Scopus and Google Scholar

- Research which is freely available for redistribution 